
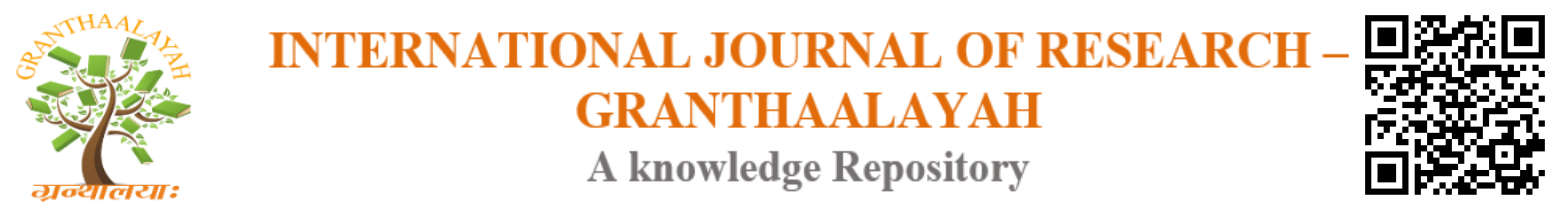

Management

\title{
CAPITAL FLOWS AND ECONOMIC GROWTH IN NIGERIA: AN ECONOMETRIC APPROACH
}

\author{
Balogun Taiwo Gabriel ${ }^{1}$, Okafor John ${ }^{2}$, Ihayere Oseghale Baryl ${ }^{3}$ \\ 1,2 Doctorate Student, Department of Economics and Statistics, University of Benin, Benin City, \\ Edo State, Nigeria \\ ${ }^{3}$ Lecturer, Department of Statistics, University of Benin, Benin City, Edo State, Nigeria
}

\begin{abstract}
On the front burner of developing countries' economic policy is the pursuit of economic growth and development. This however has been hindered by inadequate resources needed to drive the process of growth and development. One of the key components fronting the movement in support of economic globalization and integration is capital flows considering its complementarity effect in bridging the gap between domestic savings and investment. This study therefore examines the impact of capital flows on economic growth in Nigeria using data covering the period 1981 to 2016 and sourced from the Central Bank of Nigeria. The method of error correction model framework and autoregressive distributed lag was adopted in estimating our specified model. Findings from our estimated model reveal that capital flows significantly affect economic growth in Nigeria. The study thus recommends that, sound, robust and vigorous economic policies be formulated with the sole purpose of attracting and drawing capital flows into the country that helps to bridge the needed capital for economic growth and development in Nigeria.
\end{abstract}

Keywords: Capital Flow; Economic Growth; FDI.

JEL Classification: F2; 047; C100.

Cite This Article: Balogun Taiwo Gabriel, Okafor John, and Ihayere Oseghale Baryl. (2019). "CAPITAL FLOWS AND ECONOMIC GROWTH IN NIGERIA: AN ECONOMETRIC APPROACH." International Journal of Research - Granthaalayah, 7(9), 183-199. https://doi.org/10.29121/granthaalayah.v7.i9.2019.601.

\section{Introduction}

The desire for capital by developing countries as complement to domestic savings for growth and development has existed for many decades. This is spurred by the gap between savings and investments required to sustain economic growth and evidenced by the attention given to the drive for foreign capital as an important source of augmenting the saving-investment gap in most resource deficient economies especially in developing countries (Adeola, 2017; Orji, Uche and Ilori, 2014; Nwosa and Amassoma, 2014). This has led to the arguments that external financing is 
critical if not inevitable for the sustained growth of countries like Nigeria (Adegboye, Ogbebor and Egharvba, 2014). As put succinctly by Essien and Onwioduokit (1999), the need for foreign capital arises when the desired investments exceed actual savings and investments with long gestation periods that generate monetary returns and growing government expenditure that are not tax financed. The long run development of an emerging economy like Nigeria would require persistent and massive investment expenditures that can match the dire need for capital (Adegboye et al, 2014). Due to the dynamism of the core economic underpinnings, several means are continuously being explored to attain these goals. One of the measures is to open the trade among nations and accelerate the smooth flow of foreign direct investment (Okafor, Ogochukwu and Chijundu, 2016). A priori, the current reforms engineered in most developing countries' economies such as Nigeria, spanning through the financial sector, public sector and the private sector supports the fact that foreign capital flow is a factor for economic growth and development (Ekwe and Inyiama, 2014).

However, controversy regarding the costs and benefits of capital flows through the concept of globalization has taken center stage in policy and academic circles. While concerns over the benefits of capital mobility once voiced by John Maynard Keynes during the design of the Bretton Woods System were nearly forgotten in the 1970s and 1980s, the crises of the last decade have revived the debate over the merits of international financial integration (Alfaro, Kalemli-Ozcan and Volosovych, 2007). The most powerful argument in favor of international capital mobility, voiced by, among others, Fischer, Obstfeld, Rogoff and Summers (2000), is that it facilitates an efficient global allocation of savings by channeling financial resources to their most productive uses, thereby increasing economic growth and welfare around the world. Nonetheless, massive capital inflows create a strong challenge for economic managers in the conduct of macroeconomic policies. This is because attempts at curbing exchange rate appreciation through monetary policy tightening, may even result in additional inflow of foreign capital into the domestic economy (given that higher interest differentials are signals for higher returns) and thereby putting further pressure on the exchange rate. Even if international capital flows do not trigger excess volatility in domestic financial markets, it is still true that large capital inflows can spark off inflation in the presence of a fixed exchange-rate regime (Kaminsky, 2005). Similarly, transitory capital inflows may distort relative prices, with the domestic economy losing competitiveness as a result of the appreciation of the real exchange rate (Kaminsky, 2005; Caruana, 2011).

Few studies have been carried out to examine the relative impacts of several components of capital flows on economic growth (Driffield and Jones, 2013; Reisen and Soto, 2001; Aizenman, Jinjarak and Park, 2013). Many of the studies carried out in Nigeria have focused on one component especially foreign direct investment or foreign portfolio investment (Adelegan, 2000; Akinlo, 2004; Fasanya, 2012; Ugochukwu, Okore and Onoh, 2013; Obiechina and Ukeje, 2013; Okafor, Ugochukwu, and Chijindu, 2016; Ajide, 2014; Ekwe and Inyiama, 2014; Baghebo and Apere, 2014; Chigbu, Ubah, and Chigbu, 2015). However, this study examines the possible differential effect of capital inflow components on growth unlike existing studies on Nigeria.

\section{Literature Review}

Olotu and Jegbume (2011) examined foreign capital flows in the Nigerian growth equation with a focus on foreign portfolio investment and adopting impact assessment model show that foreign 
portfolio investment has a positive relationship with rate of growth of real nonoil gross domestic products. Modou and Liu (2017) in their study of 13 West African countries using data from 1985 to 2015 found that both trade and FDI significantly contribute to economic growth and the existence of unidirectional and bidirectional causality between FDI and trade on economic growth respectively. Saibu (2014) investigate the effect of capital inflow on economic growth using principal components analysis and autoregressive distributed lag (ARDL) bound testing methodology found that capital inflow when interacted with trade openness has significant impact on growth hence providing empirical support for the modernization hypothesis that capital flows and trade openness are growth stimulant. Ogbebor and Egharvba (2014) using vector error correction mechanism on Nigeria's quarterly data between 1981 and 2012 revealed that capital flows, with a focus on foreign direct investment, portfolio investment and external debt, have significant effects on economic growth within the period covered by the study. Baghebo and Apere (2014) using data covering the period 1986 to 2011 with a focus on foreign portfolio investment show that foreign portfolio investment has a positive long run and significant impact on growth within the period covered. Ekwe and Inyiama (2014) empirical assessment of foreign capital flows impact on economic growth in Nigeria from 1980 to 2012 revealed that capital flows exert positive and significant impact on growth within the period under review. Ezirim, Chinedu, Muoghalu and Emenyonu (2006) examination of the impacts of capital flows on economic growth with focus on external debt and foreign direct investments remittances reveal existence of dual causality between external debt and foreign direct investments in Nigeria and both foreign direct investment and external debt do not contribute positively and significantly to growth in Nigeria. Nkoro and Furo (2012) assessment of the impact of foreign capital inflows on economic growth in Nigeria using the tools of cointegration, variance decomposition and impulse response analysis and block exogeneity tests revealed the existence of causal relationship between growth and capital inflows with capital flows imposing a significant impact on growth. Okodua (2009) examined the impact of foreign direct investment. Okodua (2009) assessed the sustainability of the relationship between foreign direct investment and growth in Nigeria using Johansen cointegration framework and multivariate vector autoregressive model. Outcome of his study shows the existence of long run equilibrium interaction between growth and foreign direct investment inflows. Obiechina and Ukeje (2013) assessed the impact of capital flows on economic growth in Nigeria using time series data from 1970-2010 and the Engle-Granger econometric technique. Findings from their study revealed that foreign direct investment weakly affect economic growth in the short run with exogeneity test confirming the weak relationship between foreign direct investment and growth. Obiechina and Ukeje (2013) assessed the impact of capital flows on economic growth in Nigeria using time series data from 1970-2010 and the Engle-Granger econometric technique. Findings from their study revealed that foreign direct investment weakly affect economic growth in the short run with exogeneity test confirming the weak relationship between foreign direct investment and growth. Levine and Carkovic (2002) examined the relationship between foreign direct investment and economic growth with a cross section and panel data using ordinary least square (OLS) and generalized moment method (GMM). Findings show that foreign direct investment inflows do not bear a significant influence on economic growth. Chloe (2003) investigate the relationship between growth and foreign direct investment of 80 countries with 25 years sample period using Panel Vector Autoregressive model. Result of the study show that causality between growth and FDI is stronger. 


\section{Theoretical Framework}

The theoretical framework for the for the study is the endogenous-growth AK model developed by Frankel (1962) and modified by Rebelo (1991) and Pagano (1993) in explaining the connection between finance and growth. The AK model is an extension of the endogenous model of economic growth that investigate the connection between capital flows and economic growth. The AK model exhibit endogenous growth assuming that capital is the only input into production and that there is constant return to scale. With these assumptions the production function can be given as:

$Y_{t}=\alpha K_{t} \ldots \ldots \ldots \ldots \ldots \ldots \ldots \ldots \ldots \ldots \ldots \ldots \ldots \ldots$

Where $\mathrm{Y}$ is total output in period $\mathrm{t}, \mathrm{K}$ is stock of capital in period $\mathrm{t}$ and $\alpha$ is the total factor productivity growth or marginal productivity of capital.

Constant returns to scale ensure that output grows at the same rate as capital stock. However, to ensure sustained growth, we match increases in capital with equal growths in other inputs. As such, human capital with technical progress embodied in the quality of labor introduced into equation 3.1. Thus, equation 3.1 becomes;

$Y_{t}=f\left(K_{t}, H_{t}\right)$

Where $\mathrm{H}$ is the level of human capital. When human capital is incorporated into the model the role for policy is extended. Endogenous growth can arise when capital and labor are augmented by additional inputs in the production function. However, if we assume human capital to be constant, that is equal to 1 , equation 3.2 reduces to:

$Y_{t}=f\left(\alpha K_{t}, 1\right) \ldots \ldots \ldots \ldots \ldots \ldots \ldots \ldots \ldots \ldots \ldots \ldots \ldots \ldots \ldots \ldots \ldots \ldots$

Now, if we assume there are no growth in population, and only one good is produced that is consumed or invested. If this only one good is invested and capital stock is depreciating in every period at a rate of $\lambda$, gross investment becomes:

$I_{t}=K_{t+1}-(1-\lambda) K_{t} \ldots \ldots \ldots \ldots \ldots \ldots \ldots \ldots \ldots$

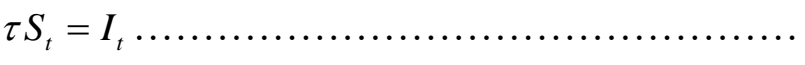

$g_{y}=\alpha\left(\frac{I}{Y}\right)-\lambda=\alpha \tau s-\lambda \ldots \ldots \ldots \ldots \ldots \ldots \ldots$

Equation 3.4 implies that total investment in period $\mathrm{t}$ equals change in capital stock minus depreciation. However, recall our assumption of a closed economy and as a result all domestic savings equals investment as shown in equation $3.4 \mathrm{~b}$ where $(1-\tau)$ is the amount charged by financial intermediary for financial services rendered (Opperman, 2016) and $\tau$ is the proportion of savings left for investment. Equation 3.5 shows the growth rate of output in a closed economy where investment depends on domestic savings where $g_{y}$ is the growth rate of output. In equation 
3.5, s represents the savings rate. Moreover, if foreign capital is allowed such that the economy becomes open and foreign investors are allowed to invest in the economy either through direct investment or portfolio investment, equation $3.4 \mathrm{~b}$ becomes;

$\tau\left(S_{t}+C F_{t}\right)=I_{t}^{*}$

Where $C F$ is capital flows, $S$ as domestic savings and $I$ as in. Given equation 3.6, the steady-state growth rate is given as:

$g_{y}^{*}=\alpha^{*} \tau^{*} s^{*}-\lambda$

Where there is international capital flows it is expected that $g_{y}^{*}$ be greater than $g_{y}, s^{*}$ be greater than $s$, and as a corollary $I_{t}^{*}$ is greater than $I_{t}$. Equation 3.7 describe how capital flows affect long run growth of an economy. Decoding this theory into empirical specification by integrating capital flows and other macroeconomic variables, equation 3.7 can be specified thus:

$$
g_{y}=\beta_{0}+\beta_{1 t} \Delta Z_{i t}+\beta_{2 t} \Delta C F_{i t}+\beta_{3} \Delta O P N_{t}+e_{t} \ldots \ldots \ldots
$$

Where $g_{y}$ is the growth rate, $\mathrm{Z}$ is omnibus variable capturing other macroeconomic variables affecting growth, CF is capital flows (like foreign direct investment, foreign capital flows, etc) and OPN is the variable capturing the degree of trade openness.

\subsection{Model Specification}

Following our theoretical framework, we specify our model thus:

$$
r g d p_{t}=\beta_{0}+\beta_{1} f d i_{t}+\beta_{2} f p i_{t}+\beta_{3} \operatorname{exd}_{t}+\beta_{4} t_{o p n_{t}}+\beta_{5} \operatorname{exr}_{t}+\varepsilon_{t} \ldots \ldots \ldots \ldots \ldots
$$

However, with the estimation of short and long run equilibrium impact of capital flows on economic growth, the static model is re-specified to capture the error correction mechanism that adjust the economy back to equilibrium in the event of shock. Thus, re-specifying equation 3.8 gives:

$$
r g d p_{t}=\beta_{0}+\beta_{1} f d i_{t}+\beta_{2} f p i_{t}+\beta_{3} \operatorname{exd}_{t}+\beta_{4} t o p n_{t}+\beta_{5} \operatorname{exr}_{t}+\phi e c m(-1)+\varepsilon_{t} \ldots
$$

Where; $r g d p$ is the real gross domestic product used to proxy output growth.

$f d i$ is foreign direct investment

$f p i$ is foreign portfolio investment

exd is external or foreign debt

topn is trade openness

exr is exchange rate

$\beta$ 's are the parameters

$\phi$ is error correction parameter

$\varepsilon$ is the random error term

$\mathrm{t}$ is time 
Considering the theoretical framework enunciated above, we expect all the parameters to be estimated to be positively related to economic growth. Essentially, we expect that: $\beta_{1}>0, \beta_{2}>0, \beta_{3}>0, \beta_{4}>0, \beta_{5}>0$

\section{Data Presentation and Analysis}

\subsection{Descriptive Statistics}

Table 4.1: Descriptive Statistics Result

\begin{tabular}{|l|l|l|l|l|l|}
\hline & Mean & Median & Max & Min & Std. Dev. \\
\hline RGDP & 31757.15 & 22391.14 & 69023.93 & 13779.26 & 18151.71 \\
\hline FDI & 291.2784 & 110.8718 & 1234.639 & 0.264300 & 359.1359 \\
\hline FPI & 160.8523 & 0.583670 & 2361.305 & -403.3414 & 485.4758 \\
\hline EXD & 1212.816 & 625.1685 & 4890.270 & 2.331200 & 1390.059 \\
\hline TOPN & 0.145077 & 0.093591 & 0.456130 & 0.000978 & 0.147073 \\
\hline EXR & 76.59172 & 57.37220 & 253.4923 & 0.610025 & 72.03856 \\
\hline
\end{tabular}

Source: Researcher's Computation (2018) using E-Views 9.0

Table 4.1 presents a summary of the descriptive statistics of the dependent and independent variables for the period of years 1981 to 2016 with a total of 36 observations. The descriptive result as reported in table 4.1 describe the attributes and/or characteristics of the data used in the study and provide summaries about the sample and measures. Key statistics reported include mean, standard deviation, maximum and minimum value.

From the above table the average real gross domestic product over the period 1981 to 2016 is given as $\$ 31,757.15$ billion with a standard deviation, the dispersion relative to the mean, given as 18,151.71 billion. The highest value of real gross domestic product during the period under study is $¥ 69,023.93$ billion and lowest value given as $\$ 13,779.26$ billion. Average figure for net foreign direct investment during the period 1981 and 2016 is 291.27 billion with a standard deviation of $\$ 359.13$ billion. Highest figure of net foreign direct investment flow into the country during the period is $\$ 1,234.63$ billion and the lowest figure is $\$ 0.264$ billion. Reported average value of net foreign portfolio investment during the period is 160.85 billion with associated standard deviation of $\$ 485.47$ billion. Highest and lowest band of net foreign portfolio investment flow into the country is reported as $\$ 2,361$ and ( $\$ 403.34$ ) billion respectively. Average foreign debt incurred during the period under study is reported as $1,212.82$ billion with a standard deviation of $\$ 1,390.05$ billion. Highest and lowest value of foreign debt incurred during the period are $\$ 4,890.27$ and $\$ 2.331$ billion respectively. Average degree or intensity of international trade, described as trade openness, within the period is 0.145 with a standard deviation of 0.147 . The highest measure of trade intensity is 0.456 while the lowest intensity given as 0.0009 . Lastly, average exchange rate in the country during the period is $\$ 76.59 / \$ 1$ with a standard deviation relative to the mean given as 72.04 and the highest and lowest exchange rate during the period are $\$ 253.49 / \$ 1$ and $¥ 0.61 / \$ 1$ respectively. 


\subsection{Normality}

The Jarque Bera statistic tests for normality of the distribution around the mean. It is a goodness of fit test that ascertain the skewness and kurtosis of the data. Skewness measures the extent to which a distribution is not symmetric about its mean value and kurtosis measures how it is fat the tails of the distribution. If the probability value of the Jarque Bera value is greater than 0.05, there is the presence of normality and if less than 0.05 it is otherwise.

Table 4.2: Normality Result

\begin{tabular}{|c|c|c|c|}
\hline & \multicolumn{3}{|c|}{ Jarque-BeraProbabilitySkewnessKurtosis } \\
\hline RGDF & 5.289229 & 0.071033 & 0.8748642 .318378 \\
\hline FDI & 6.731444 & 0.034537 & 1.0563332. \\
\hline FPI & 283.6182 & 0.000000 & \begin{tabular}{|l|l|}
3.440733 & 14.90480 \\
\end{tabular} \\
\hline EXD & 10.11009 & 0.006377 & $1.281563 \quad 3.412852$ \\
\hline TOPN & 3.88 & 0.143147 & 0.6200601 .973382 \\
\hline EXR & 2.620939 & 0.269693 & 0.4237301 .985552 \\
\hline
\end{tabular}

\section{Source: Researcher's Computation (2018) using E-Views 9.0}

From the table above, the normality test on each of the variables shows that real gross domestic product, trade openness and exchange rate are normally distributed with the probability value associated with their respective Jarque Bera statistics greater than 5\% (percent). Meanwhile, the trio of foreign direct investment, foreign portfolio investment and external debt have no normal distribution.

\subsection{Correlation Analysis}

Correlation measures the extent or size of linear association or relationship between variables. Values of the correlation coefficient are between plus one (+1) and minus one (-1). A correlation coefficient of +1 indicates the existence of a perfect positive association between the two variables, while a correlation coefficient of -1 indicates perfect negative association. A correlation coefficient of zero, on the other hand, indicates the absence of relationship (association) between two variables (Brooks, 2008). The table below shows the correlation matrix among dependent and independent variables.

Table 4.3: Correlation Result

\begin{tabular}{|l|l|l|l|l|l|l|}
\hline \multicolumn{7}{|c|}{ Correlation } \\
\hline Probability & RGDP & FDI & FPI & EXD & TOPN & EXR \\
\hline RGDP & 1.000000 & & & & & \\
\hline & ----- & & & & & \\
\hline FDI & 0.843190 & 1.000000 & & & & \\
\hline & $0.0000 * * *$ & ---- & & & & \\
\hline FPI & 0.540993 & 0.450455 & 1.000000 & & & \\
\hline & $0.0007 * * *$ & $0.0058 * * *----$ & & & \\
\hline EXD & 0.323867 & 0.167347 & 0.051924 & 1.000000 & & \\
\hline & $0.0540 * *$ & 0.3293 & 0.7636 & ---- & & \\
\hline TOPN & 0.930116 & 0.930912 & 0.545149 & 0.294354 & 1.000000 & \\
\hline
\end{tabular}




\begin{tabular}{|c|c|c|c|}
\hline \multirow{2}{*}{\begin{tabular}{|l} 
EXR \\
\end{tabular}} & $0.0000 * * * 0.0000 * * * 0.0006 * * * 0.0814$ & ----- & \\
\hline & \begin{tabular}{|l|l|l|l|l}
0.914485 & 0.801079 & 0.415981 & 0.618152 \\
\end{tabular} & 0.874535 & 1.000000 \\
\hline & $0.0000 * * * 0.0000 * * * 0.0116 * * * 0.0001 * *$ & $0.0000 * * *$ & ----- \\
\hline
\end{tabular}

**Significant at $5 \%$ level of significance

***Significant at $1 \%$ level of significance

\section{Source: Researcher's Computation (2018) using E-Views 9.0}

The correlation results as reported in Table 4.2 above shows that foreign direct investment, foreign portfolio investment, external debt, trade openness and exchange rate have positive correlation with real gross domestic product. This implies that as these variables move in an upward direction, real gross domestic product move in the same direction. Foreign direct investment as shown in the above table 4.3 has positive correlation with foreign portfolio investment, external debt, trade openness and exchange rate. Similarly, foreign portfolio investment has positive correlation with external debt, trade openness and exchange rate. Also, external debt, as shown in the table, has positive correlation with trade openness and exchange rate. Lastly, trade openness is positively associated with exchange rate.

\subsection{Autoregressive Distributed Lag Model}

Autoregressive distributed lag model (ARDL) provides for the estimation of both short run and long run effect of the explanatory variables on the explained variables. Reported are the short run and long run impact of the control variables on the dependent variables.

Table 4.4: Pesaran/Shin/Smith ARDL Bound Test

\begin{tabular}{|l|l|l|l|}
\hline & Computed Stat. & \multicolumn{2}{|l|}{ Critical Values at 5\% (percent) } \\
\hline F-statistic & $\mathrm{F}=40.452$ & $\mathrm{I}(0)$ & 2.62 \\
\cline { 3 - 4 } & & $\mathrm{I}(1)$ & 3.79 \\
\hline \multirow{2}{*}{ t-statistic } & $\mathrm{t}=-7.994$ & $\mathrm{I}(0)$ & -2.86 \\
\cline { 3 - 4 } & & $\mathrm{I}(1)$ & -4.19 \\
\hline
\end{tabular}

\section{Source: Researcher's Computation (2018) using Stata 13}

The reported bound test examines the existence or otherwise of cointegration among the variables. It ascertains the existence of long run equilibrium in the estimated Autoregressive Distributed Lag model (ARDL). From the table above, the result of the bound test shows that the reported $f$ statistics and t-statistics are higher than the upper bound critical value of 3.79 and -4.19 respectively implying that the underlying null hypothesis of no cointegration for the model is rejected at 5\% (percent) conventional level of significance and confirming the existence of long run equilibrium among the variables.

Table 4.5: Autoregressive Distributed Lag Model (ARDL) Result

\begin{tabular}{|l|l|l|l|l|}
\hline Variable & Coefficient & Std Error & t-statistics & Probability \\
\hline Long run Effect & & & & \\
\hline FDI & 332.7858 & 23.09002 & 14.41 & $0.005^{* * *}$ \\
\hline FPI & 57.44478 & 3.56814 & 16.10 & $0.004 * * *$ \\
\hline EXD & 23.81743 & 2.690543 & 8.85 & $0.013 * * *$ \\
\hline TOPN & -566337.2 & 17762.37 & -31.88 & $0.001 * * *$ \\
\hline
\end{tabular}


DOI: 10.5281/zenodo.3472641

\begin{tabular}{|l|l|l|l|l|}
\hline EXR & -622.5952 & 106.9051 & -5.82 & $0.028^{* *}$ \\
\hline$R$-Square & 0.9992 & & Mean Dep. Var & 1692.249 \\
\hline Adj. -Square & 0.9881 & & Akaike Info. Crit & 12.09569 \\
\hline Std Error of Reg. & 160.4060 & & Schwarz criterion & 13.46982 \\
\hline F-statistic & 89.77257 & & Hanna-Quin Crit. & 12.55118 \\
\hline Prob $($ F-stat) & 0.011073 & & Durbin-watson & 3.312006 \\
\hline Log-Likelihood & -163.5311 & & & \\
\hline Short run Effect & & & & \\
\hline FDI & -90.47254 & 19.51582 & -4.64 & $0.044^{* *}$ \\
\hline FPI & 13.58389 & 4.787188 & 2.84 & 0.105 \\
\hline EXD & -3.681713 & 2.054054 & -1.79 & 0.215 \\
\hline TOPN & 110698.8 & 20003.81 & 5.53 & $0.031^{* *}$ \\
\hline EXR & 763.142 & 140.6035 & 5.43 & $0.032^{* *}$ \\
\hline Adj(ECT) & -2.173237 & .2718512 & -7.99 & $0.015^{* *}$ \\
\hline$R$-Square & 0.999995 & & Mean Dep. Var & 33918.29 \\
\hline Adj. R-Square & 0.999922 & & Akaike Info. Crit & 12.09569 \\
\hline Std Error of Reg. & 160.4050 & & Schwarz criterion & 13.46982 \\
\hline F-statistic & 13649.89 & & Hanna-Quin Crit.. & 12.55118 \\
\hline Prob (F-stat) & 0.000073 & & Durbin-watson & 3.312006 \\
\hline
\end{tabular}

Dependent variable is real gross domestic product. $* * *, * *$ and $*$ indicate the coefficients are significant are $1 \%, 5 \%$ and $10 \%$ respectively.

\section{Source: Researcher's Computation (2018) using Stata 13}

From the above result, in the long run, foreign direct investment, foreign portfolio investment and external debt have positive impact on real gross domestic product and significant at 5\% (percent) and 1\% (percent) level of significance. Essentially, and as shown in the estimated model, a naira increase in foreign direct investment will in the long run significantly raise real gross domestic product by $\$ 332.78$. Similarly, a naira increase in foreign portfolio investment will yield $\$ 57.44$ significant increase in real gross domestic product in the long run. Also, a naira increase in foreign debt incurred by the government will bring about 23.81 increase in real gross domestic product in the long run. However, the duo of trade openness and exchange rate have negative impact on economic growth in the long run with the impact significant at 5\% (percent) conventional level of significance.

The $R$-square and the adjusted $R$-square given as 0.99 and 0.98 respectively indicate that variation in real gross domestic product is largely explained by the control variables. Specifically, the adjusted $R$-square shows that $98 \%$ (percent) movement in real gross domestic product is well explained by the variables in the long run. The reported $f$-statistic shows that the overall long run model is statistically significant at $1 \%$ (percent) conservative level of significance.

The estimated short run model results of capital flow and growth is reported above. In the short run, foreign direct investment has a negative impact on economic growth with the impact significant at 5\% (percent) level of significance. Similarly, the impact of external debt on economic growth is negative albeit not significant at both $5 \%$ and $1 \%$ (percent) level of significance. On the other hand, foreign portfolio investment has positive impact on real gross domestic product albeit not significant at 5\% (percent) level of significance. Meanwhile, the impact of trade openness and 
exchange rate on economic growth is positive with both significant at 5\% (percent) conventional level of significance.

The coefficient of the cointegration factor or error correction term is negative and significant at $1 \%$ (percent) level of significance. The error correction factor measures the speed of adjustment towards long run equilibrium. The desired effect of the error correction factor implies that the rate of variation by which growth adjust to shock per time is not significantly different from zero. The error correction term shows that speed of adjustment of economic growth to long run equilibrium in the event of shock in the equation is $2.17 \%$ (percent). This implies that $2.17 \%$ (percent) of the divergence between long run and short run real gross domestic product is remedied within a year.

\subsection{Discussion of Findings}

Capital flows as shown above exhibit positive and significant impact on economic growth particularly in the long run. Essentially, whereas foreign direct investment might pose a negative impact on growth in the short run, it goes to have a significant impact on growth in the long run. The negative impact of foreign direct investment in the short run as noted by Borenzstein et al (1998) can be crucially due to inadequate absorptive capacity that depends on opening threshold of human capital stock. The result is also consistent with the findings of Adeola (2017), Okonkwo, Egbunike and Udeh (2015). However, the long run positive impact of foreign direct investment on growth is consistent with the findings of Saibu (2014), Nkoro (2012), Ayanwale (2007), Okodua (2009), Tiwari and Mutascu (2011). Foreign portfolio investment has positive weak impact in the short run but does have a positive and significant impact in the long run. Findings from this study is consistent with the findings of Baghebo and Apere (2014), Ibrahim and Akinbobola (2017) and negates the findings of Durham (2003), Dimitrios et al. (2005) and Houssem and Hichem (2011) Olotu and Jegbefume (2011). Trade openness has strong and positive impact on growth in the short run, however the impact turns negative in the long run. The long run negative impact of trade openness can be justified with the findings of Rodrik (1992) that state that trade openness could cause macroeconomic volatility enhancing inflation, deflating exchange rates and resulting in balance of payment crisis that consequently impact on growth. Similarly, Matteis (2004) state that trade openness place exogenous constraints to economic growth by contributing to impose their reliance on global demand and to amplify their exposure to the volatility of international markets. Levine and Renelt (1992) also established that trade openness negatively impacts local investments. External debt has negative impact on economic growth in the short run, and turns positive in the long run. The result is consistent with findings of Adegboye, Garba and Egharvba (2014). It however negates the findings of Quattara (2006).

\section{Summary}

The main thrust of this research work is to ascertain the impact of capital flows on economic growth in Nigeria. Essentially, the work attempt to critically identify the impact of capital flows on Nigerian economic growth using data from 1981-2016. The study adopted an econometric method of analysis and data were sourced from the Central Bank of Nigeria. Descriptive statistical analysis was carried out on the data to establish the characteristics and/or attributes of our datasets. Correlation analysis was further tested for to determine the degree of association among the variables. Stationarity test using Augmented Dickey Fuller test was applied to ascertain the order 
of integration and to check for the possibility of each of variables having unit root. Johansen cointegration test was performed to verify the existence of long run equilibrium relationship among the variables. Given the existence of long run equilibrium as evidenced by Johansen cointegration test, error correction model estimation technique was conducted on the specified model. Consequent on the result of the error correction model, given the error correction coefficient not in consonance with econometric theory by assuming a positive but significant value, autoregressive distributed lag model bound test was conducted to further prove the existence of long run equilibrium relationship between capital flow and economic growth. The result of the bound test further shows the existence of long run equilibrium relationship and consequently autoregressive distributed lag model techniques was applied on the specified model and the short run effect, long run effect and the error correction factor or term that correct for disequilibrium in the model reported.

Empirical findings from this study shows that:

1) Foreign direct investment has negative impact on economic growth in the short run, but in the long run, positively and significantly impact economic growth implying that an increase of FDI flows will affect growth rate negatively in the short run, and in the long run, positively stimulate growth rate in Nigeria.

2) Foreign portfolio investment has weak positive effect on economic growth in the short run, but impose strong and significant impact on growth in the long run. This uncover the importance of foreign portfolio investment in spurring economic growth.

3) External or foreign debt has negative and significant impact on economic growth in the short run but as proceeds of foreign debt are put into infrastructural and other development activities, external debt stimulate growth as evidenced by the long run estimates which is positive and significant.

4) Trade openness impact growth positively in the short run, but in the long run the degree of openness impact economic growth negatively.

Similar to what was obtained for trade openness, exchange rate positively impacts economic growth in the short run but turns to impact growth negatively in the long run. The implication of this is that volatility of exchange rate may not be felt in the short run, but the impact can turn to hurt growth rate in the long run.

\section{References}

[1] Abidemi C., A. Adegboye, O. Ogbebor and M. I. Egharvba, (2014). External capital flows and economic growth in Nigeria, Journal of Research in National Development, Vol. 12 (2).

[2] Adelegan, J. O. (2000). Foreign direct investment and economic growth in Nigeria: A seemingly unrelated model. African Review of Money Finance and Banking, (5)25.

[3] Adeola, O. O. (2017). Foreign capital flows and economic growth in selected Sub-Saharan African economies, Dissertation presented for the degree of Doctor of Philosophy in Development Finance (Faculty of Economics and Management Sciences) at Stellenbosch University.

[4] Aghion P. and P. Howitt, (1992). A model of growth through creative destruction, Econometrica, 60(2), pp. 323-351.

[5] Aghion P., D. Comin, and P. Howitt, (2006). When does domestic saving matter for economic growth? National Bureau of Economic Research Working Papers, 12275.

[6] Aizenman, J., Y. Jinjarak and D. Park, (2013). Capital flows and economic growth in the era of financial integration and crisis, 1990-2010, Open Economies Review, 24(3), 371-396. 
[7] Ajide, K. B. (2014). Determinants of economic growth in Nigeria, CBN Journal of Applied Statistics, 5(2), 147-170.

[8] Akinlo, A. E. (2004). Foreign direct investment and growth in Nigeria: An empirical investigation, Journal of Policy Modeling, 26 (5), 627-639.

[9] Akram, N. (2013). Empirical examination of debt and growth nexus in South Asian countries, East Asian Development Model, 20(2), 29-52.

[10] Alfaro, L., S. Kalemli-Ozcan, and V. Volosovych, (2007). Capital controls and capital flows in emerging economies: policies, practices and consequences. University of Chicago Press

[11] Anyanwu J. C. (1997). Nigeria's public finance. Awka, Joanee Educational Publishers Limited.

[12] Anyanwu J. C. (1993). Monetary Economics: Theory, policy and institution. Onitsha, Hybrid publishers Limited.

[13] Arnone, M., L. Bandiera, and A. Presbitero, (2005). External debt sustainability: Theory and empirical evidence, Available: http://www3.unicatt.it/dipartmenti/DISES/allegati/ArnoneBandieraPresbitero.pdf.

[14] Asogwa C. R. and C. C. Ezema (2004). Domestic government debt, structure risk characteristics and monetary policy conduct: evidence from Nigeria. International Research Project on Macroeconomic Policy Challenges for Low Income Countries.

[15] Ayanwale, A. B. (2007). FDI and economic growth: evidence from Nigeria. AERC Research Paper 165. Nairobi, African Economic Research Consortium.

[16] Baghebo, M. and T. O. Apere, (2014). Foreign portfolio investment and economic growth in Nigeria, International Journal of Business and Social Science, Vol. 5, No. 11(1).

[17] Barro R. (1990). Government spending in a simple model of endogenous growth, Journal of Political Economy, 98, pp. S103-S125.

[18] Barro R. J. and X. Sala-i-Martin, (1995). Economic Growth, New York: McGraw-Hill.

[19] Barro R. J., (1989). A cross-country study of growth, saving, and government, National Bureau of Economic Research Working Paper, 2855.

[20] Barro R. J., (1991). Economic growth in a cross section of countries, Quarterly Journal of Economics, 106 (2), 407-443.

[21] Barro R. J., (1997). Determinants of economic growth: A cross-country empirical study, Cambridge MA, MIT Press.

[22] Barro R. J., (2003). Determinants of economic growth in a panel of countries, Annals of Economics and Finance, 4, 231-274

[23] Barro, R. J., and J. W. Lee (1994). Losers and Winners in Economic Growth. Proceedings of the World Bank Annual Conference on Development Economics, 267-297.

[24] Baum, A., C. Checherita-Westphal, and P. Rother (2013). Debt and growth: New evidence for the Euro area, Journal of International Money and Finance, 32, 809-821.

[25] Beck, T., R. Levine and N. Loayza (2000). Finance and the Sources of Growth, Journal of Financial Economics, 58, 261-300.

[26] Benhabib J. and M. Spiegel. (1994). The role of human capital in economic development: Evidence from aggregate cross-country data, Journal of Monetary Economics, 34, pp. 143-173.

[27] Benhabib, J. and M. M. Spiegel (2000), The Role of Financial Development in Growth and Investment, Journal of Economic Growth, 5, 341-360.

[28] Bergoeing R., J. Patrick, T. Kehoe, J. Kehoe, and R. Soto. (2002). Policy-driven productivity in Chile and Mexico in the 1980's and 1990's, American Economic Review, 92(2): 16-21.

[29] Bernanke, B. S. and R. S. Gurkaynak (2001). Is growth exogenous? Taking Mankiw, Romer, and Weil seriously. National Bureau of Economic Research Working Paper, 8365.

[30] Bhagwati, J. (1998). The capital myth. Foreign Affairs 77 (3): 7-12.

[31] Borensztein, E., J. D. Gregorio, and J. W. Lee, (1998). How does foreign direct investment affect economic growth? Journal of International Economics, 45, 115-135.

[32] Brooks, C. (2008). Introductory Econometrics for Finance. New York, Cambridge University Press. 
[33] Buch, C. and C. Pierdzioch (2000). The growth and volatility of international capital flows: Reconciling the evidence, Paper prepared for the Kiel Week Conference held in Kiel, June, 19-20, 2000.

[34] Caruana, J. (2011). Capital flows to the emerging market economies: a perspective on policy challenges, Forty-sixth SEACEN Governors' Conference, Colombo, Sri Lanka, 24-26 February, 2011.

[35] Chenery, H. and A. M. Strout, (1966). Foreign assistance and economic development, The American Economic Review, 56(4), 679-733.

[36] Chigbu, E. E., C. P. Ubah, and U. S. Chigbu (2015). Impact of capital inflows on economic growth of developing countries, International Journal of Management Science and Business Administration, Vol. 1 (7) $7-21$.

[37] Choe, J. I. (2003). Do foreign direct investment and gross domestic investment promote economic growth? Review of Development Economics, 7(1), 44-57.

[38] Chorn, S. and D. Siek, (2017). The impact of foreign capital inflow on economic growth in developing countries, Journal of Finance and Economics, Vol. 5, No. 3, 128-135.

[39] Chowdhury, A. R., and G. Mavrotas, (2005). FDI and growth: A causal relationship. WIDER Research Paper, 2005/25. Helsinki: UNU-WIDER.

[40] Coe, D. T and E. Helpman, (1993). International R\&D Spillovers, C.E.P.R. Discussion Papers. CEPR Discussion Papers, 840.

[41] Commonwealth Treasury (1964). The meaning and measurement of economic growth, Treasury Information Bulletin, Commonwealth Treasury, Canberra.

[42] De Gregorio, J. and P. E. Guidotti (1995). Financial development and economic growth, World Development 23 (3), 433-448.

[43] Dickey, D. A., and W. A. Fuller (1979). Distributions of the estimators for auto-regressive

[44] Doppelhofer G., X. Sala-i-Martin, and R. I. Miller (2004). Determinants of long-term growth: A Bayesian averaging of classical estimates (BACE) approach, American Economic Association, Vol. 94(4).

[45] Driffield, N. and C. Jones (2013). Impact of FDI, ODA and migrant remittances on economic growth in developing countries: A systems approach. The European Journal of Development Research, 25(2), 173-196.

[46] Dritsakis, N., E. Varelas, and A. Adamopolous, (2003). The main determinants of economic growth: an empirical investigation with granger causality analysis for Greece, Journal of Economics.

[47] Durham, J. B. (2003). Foreign portfolio investment, foreign bank lending and economic growth, International Finance Discussion Papers Number 757.

[48] Easterly, W. (2003). Can foreign aid buy growth? The Journal of Economic Perspectives, 17(3), 23-48.

[49] Easterly, W., and S. Rebelo, (1993). Fiscal policy and Economic Growth: An empirical investigation, Journal of Monetary Economics,32, 417-458.

[50] Edo S. E. (2011). Capital market development in an emerging economy and the challenge of fostering foreign participation. International Journal of Monetary Economics and Finance, 4(2):195-215.

[51] Edu, G. T., L. Inaya, and A. F. Bassey, (2015). Foreign private capital inflows and economic growth in Nigeria, European Journal of Business and Social Sciences, Vol. 4, No. 08, 205 - 217.

[52] Ekwe, M. C. and O. I. Inyiama, (2014). Foreign capital flows and growth of the Nigeria economy: An empirical review, International Journal of Economics and Finance, Vol. 6 (4).

[53] Essien, E.A and E.A. Onwioduokit, (1999). Capital flows to Nigeria: Issues and determinants, Central Bank of Nigeria (CBN) proceedings of the Eight Annual Conference of the Zonal Research Units on the theme, Evaluating Investment Performance for Re-invigorating Growth and Development in Nigeria, Pp 88. 
[54] Ezirim, B., M. Chinedu, I. Muoghalu, and E. N. Emenyonu, (2006). Can the St. Louis model effectively explain output-debt relation in an emerging African country? Paper Presented at the Annual Conference of the American Academy of Accounting and Finance in New Orleans, Louisiana, December, 9-11.

[55] Fasanya, I. O. (2012). Capital flows-growth nexus in Nigeria: Has foreign direct investment played a role in accelerating economic growth. Journal of Sustainable Development in Africa, 14(8), 3452.

[56] Feldstein, M. (1999). International capital flows. Illinois, University of Chicago Press

[57] Flammang, R. A. (1979). Economic growth and economic development: Counterparts or competitors? EDCC, 28: 47-61.

[58] Goldsmith, R. W. (1969). Financial structure and development. New Haven, Yale University Press.

[59] Gordon, R. J., (2002). Technology and economic performance in the American economy, NBER Working Papers 8771, National Bureau of Economic Research.

[60] Granger, C. W. J. (1986), Developments in the study of cointegrated economic variables. Oxford Bulletin of Economics and Statistics, 48, 213-27.

[61] Grossman, G.M. and E. Helpman, (1991). Innovation and growth in the global economy, MIT Press. Cambridge, MA.

[62] Gujarati, D. N. and D. C. Porter (2009). Basic Econometrics, New York, McGraw-Hill/Irwin.

[63] Haller, A. (2012). Concepts of economic growth and development. challenges of crisis and of knowledge, Economy Transdisciplinarity Cognition, Vol. 15, Issue 1, 66-71.

[64] Hameed, A., H. Ashraf, and M. A. Chaudhary, (2008). External debt and its impact on economic and business growth in Pakistan, International Research Journal of Finance and Economics, 1(20), 132-140.

[65] Hansen, H. and J. Rand, (2006). On the causal links between FDI and growth in developing countries, The World Economy, 29(1), 21-41.

[66] Harrison, A. (1994). Openness and growth: A time series, cross country analysis for developing countries, Journal of Development Economics, Vol. 48, 419-447.

[67] Harrison, A. E. (1996). Openness and growth: A time series, cross country analysis for developing countries, Journal of Development Economics, 48: 419-447.

[68] Houssem, R. and S. Hichem (2011). The impact of foreign direct investment and portfolio investment on economic growth in developing and developed economies, Interdisciplinary Journal of Research in Business, Vol. 1, 6, 10-17.

[69] Howitt, P., and P. Aghion (1998). Capital accumulation and innovation as complementary factors in longrun growth, Journal of Economic Growth, 3.

[70] Ibrahim, T. R. and T. O. Akinbobola, (2017). Foreign portfolio investment and economic growth in Nigeria democratic settings, Journal of Economics and Sustainable Development, Vol.8, No.5.

[71] IGNOU (2017). Harrod-Domar Growth Model, Unit 2, Indira Gandhi National Open University (IGNOU)

[72] IMF (2011). Public sector debt statistics: Guide for compilers and users, International Monetary Fund Publication, ISSN: 9781616351564.

[73] Iyoha M. A. (2004). Applied econometrics. Benin, Mindex Publishing.

[74] Jabbar, A. and A. G. Awan, (2014). The Determinants of Capital Inflow in Developing Countries with Special Reference to Pakistan, Developing Country Studies, Vol.4, No.12, 2014

[75] Johansen, S (1988). Statistical analysis of cointegration vectors, Journal of EconomicDynamics and Control, 12, $231-254$.

[76] Johansen, S and K. Juselius (1990). Maximum likelihood estimation and inference on cointegration with applications to the demand for the money, Oxford Bulletin of Economics and Statistics, 52, 169-210.

[77] Johansen, S and K. Juselius (1992). Testing structural hypotheses in a multivariate cointegration analysis at the purchasing power parity and the uncovered interest parity for the UK, Journal of Econometrics, 53: $211-244$. 
[78] Kaminsky, G. L. (2005). International capital flows, financial stability and growth, United Nations Department of Economic and Social Affairs Working Paper No. 10

[79] Khan, M, and M. Kumar (1997). Public and private investment and the growth process in developing countries, Oxford Bulletin of Economics and Statistics, 59, 69-88.

[80] Knight, M., N. Loayza, D. Villanueva, (1993). Testing the Neoclassical Theory of Economic Growth, A Panel Data Approach, International Monetary Fund Staff Paper, 40(3), 512-541.

[81] Krugman, P. (1998). Saving Asia: It's time to get radical. Fortune 138 (5): 74-80.

[82] Lane, P. and G. M. Milesi-Ferretti (1999). The external wealth of nations: Measures of foreign assets and liabilities for industrial and developing countries, IMF Working Paper, WP/99/115, International Monetary Fund, Washington D. C.

[83] Lane, P. and G. M. Milesi-Ferretti (2000). The external capital structure: Theories and evidence, IMF Working Paper, WP/00/152, International Monetary Fund, Washington D. C.

[84] Levine, R and D. Renelt (1992). A sensitivity analysis of cross-country growth regressions, American Economic Review, 82, 942-963.

[85] Levine, R., and M. Carkovic (2002). Does Foreign Direct Investment Accelerate Economic Growth? University of Minnesota Mimeo.

[86] Lucas, R. E. (1988). On the mechanics of economic development, Journal of Monetary Economics, 22, 3-42.

[87] Makki, S. S., and A. Somwaru (2004). Impact of foreign direct investment and trade on economic growth, American Journal of Agricultural Economics, Vol. 86, Issue 3, 795-801.

[88] Malizia, E. (2007), Economic growth and economic development: Concepts and measures, University of North Carolina

[89] Masoud, N. (2013), Neoclassical economic growth theory: An empirical approach, Far East Journal of Psychology and Business, Vol. 11 No. 3

[90] McKinnon, R. I. (1973). Money and capital market in economic development. The Brookings Institution, Washington DC.

[91] Modou, D. and Liu, H. Y. (2017). The impact of Asian foreign direct investment, trade on Africa's economic growth, International Journal of Innovation and Economics Development, Vol. 3 (1),7285.

[92] Montiel, P. and C. Reinhart (1999). Do capital controls and macroeconomic policies influence the volume and composition of capital flows? Evidence from the 1990s, Journal of International Money and Finance, 18: 619-635.

[93] Montiel, P. and C. Reinhart (2001). The dynamics of capital movements to emerging economies during the 1990s. In S. Griffith-Jones, M. Montes, A. Nasution (eds) Short term capital flows and economic crises, Oxford University Press, Oxford.

[94] Nelson, M., and R. Singh (1994). The deficit growth connection: Some recent evidence from developing countries, Economic Development and Cultural Change, 43, 167-191.

[95] Nkoro, E. (2012). Foreign capital inflows and economic growth in Nigeria: An empirical approach, Academic Journal of Interdisciplinary Studies, Vol 1 No 2.

[96] North, D. C. and R. P. Thomas (1973). The rise of the western world: A new economic history, Cambridge, UK: Cambridge University Press.

[97] Nwinee, B. F. and O. V. Olulu-Briggs (2016). Capital inflows and macroeconomic dynamics in Nigeria: an empirical review, British Journal of Economics, Management and Trade, 15(2): 1-9.

[98] Nwosa P. I. and D. Amassoma (2014). Capital inflows and exchange rate in Nigeria, Mediterranean Journal of Social Sciences, Vol 5 No 7.

[99] Obadan M. I. (2006). Capital account liberalization: Experience from the emerging market Economics. CBN Economic and Financial Review, 44(4):89-116.

[100] Obadan, M. I. (2004). Foreign capital flows and external debt: perspectives on Nigeria and the LDCS group, Lagos-Nigeria: Broadway Press Limited.

[101] Obiechina M. E. (2010). Capital flows and financial crises: Policy issues and challenges for Nigeria. CBN Economic and Financial Review, 48(1):93-112. 
[102] Obiechina, M. E. and E. U. Ukeje (2013). Economic growth, capital flows, foreign exchange rate, export and trade openness in Nigeria, International Journal of Economics and Management Sciences, Vol. 2 (9) 01-13.

[103] Obstfeld, M. and K. Rogoff (2000). The six major puzzles in international macroeconomics: Is there a common cause? NBER Macroeconomics Annual, $2000 \mathrm{Ed}$.

[104] Ogujiuba, K. and E. Obiechina (2012). Foreign private capital, economic growth and macroeconomic indicators in Nigeria: An empirical framework, International Journal of Economics and Finance, 4(10), 111-124.

[105] Okafor, I. G., U. S. Ugochukwu and E. H. Chijindu (2016). Foreign capital inflows and Nigerian economic growth nexus: A Toda Yamamoto approach, European Journal of Accounting, Auditing and Finance Research, Vol.4 (3) 16-26.

[106] Okereke, N. O. (2010). The Nigerian Stock Exchange: A review of market performance in 2009 and the outlook for 2010. Lagos: The Nigerian Stock Exchange.

[107] Okodua, H (2009). Foreign direct investment and economic growth: Co-integration and causality analysis of Nigeria, The African Finance Journal, Vol. 11, Part 1.

[108] Okodua, H. (2009). Foreign direct investment and economic growth: Co-Integration and causality analysis of Nigeria, The African Finance Journal, Vol. 11, Part 1.

[109] Okonkwo, O. N. (2016). Foreign portfolio investment and industrial growth in Nigeria, International Journal of Innovative Finance and Economics Research, 4(3):31-38.

[110] Okonkwo, R. I., F. Egbunike, and F. N. Udeh (2015). Foreign direct investment and economic growth in Nigeria. Developing Country Studies, 5(9), 47-52.

[111] Olaleye, S. O. (2015). Impact of capital flows on economic growth in Nigeria, International Journal of Economics, Commerce and Management, Vol. 3, Issue 5.

[112] Olotu, M. E. and K. Jegbefume (2011). The place of foreign capital flows in the Nigerian economic growth equation: Evidence from foreign portfolio investment, International Journal of Economic Development Research and Investment, Vol 2 No. 3.

[113] Orji, A., A. S. Uche, and E. A. Ilori (2014). Foreign capital inflows and growth: An empirical analysis of WAMZ experience, International Journal of Economics and Financial Issues, Vol. 4, No. 4, pp.971-983.

[114] Oyejide T. A. (2004). Nigeria and the IMF. Ibadan, Nigeria: Heinemann Books Ltd.

[115] Pagano, M. (1993). Financial markets and growth: An overview. European Economic Review, 37, 613-622.

[116] Papanek, G. F. (1973). Aid, foreign private investment, savings and growth in LDC, Journal of Political Economy, Vol. 81, No.1, pp 120-130.

[117] Patterson, N., M. Montanjees, J. Motala, and C. Cardillo (2004). Foreign direct investment trends, data availability, concepts, and recording practices, Washington, D.C.: International Monetary Fund.

[118] Petrakos, G. and P. Arvanitidis (2008). Determinants of economic growth, Economic Alternatives, Issue 1.

[119] Pigka-Balanika, V. (2006). The impact of trade openness on economic growth: Evidence in developing countries, Master Thesis at the Erasmus School of Economics, Erasmus Universiteit, Rotterdam

[120] Plossner, C. (1992). The search for growth in policies for long-run economic growth, Federal Reserve Bank of Kansas City, Kansas City, MO.

[121] Portes, R., and H. Rey (1999). The determinants of cross-border equity flows, NBER Working Paper, 7336, National Bureau of Economic Research, Cambridge, M. A.

[122] Portes, R., H. Rey, and Y. Oh (2001). Information and capital flows: The determinants of transactions in financial assets, European Economic Review 45: 783-796.

[123] Prasad, E., K. Rogoff, S. Wei, and M. A Kose (2003). Effects of financial globalization on developing countries: Some empirical evidence, International Monetary Fund Papers, pp, 1-86. 
[124] Pritchett, L. (1996). Measuring outward orientation in the LDCS: Can it be done? Journal of Development Economics, 49: 309-55.

[125] Quattara, B. (2006). Foreign aid and government fiscal behavior in developing countries: Panel data evidence, Economic Modelling, 23, 506-514.

[126] Rebelo, S. (1991). Long-run policy analysis and long-run growth. Journal of Political Economy, 99, 500-521.

[127] Reisen, H. and M. Soto, (2001). Which types of capital inflows foster developing-country growth? International Finance, 4(1), 1-14.

[128] Robinson, J. (1952). The generalization of the general theory and other essays. St Martin's Press, New York.

[129] Rodrik, D. (1992). The limits of trade policy reforms in developing countries. The Journal of Economic Perspectives, 6(1), 87-105.

[130] Rodrik, D. (1998). Who needs capital account convertibility? Princeton Essays in International Finance 207:55-65.

[131] Rodrik, D. and A. Velasco (1999). Short term capital flows. NBER Working Paper, 7364, National Bureau of Economic Research, Cambridge, M. A.

[132] Romer P. (1986). Increasing returns and long run growth, Journal of Political Economy, 94(2), 1002-1037.

[133] Romer, P. (1990). Endogenous technological changes. Journal of Political Economy, 98 (5), S71 S103.

[134] Roubini, N. and X. Sala-i-Martin (1992). Financial repression and economic growth, Journal of Development Economics, 39, 5-30.

[135] Saibu, O. (2014). Capital inflow and economic growth nexus in Nigeria: The role of trade openness, Acta Universitatis Danubius Vol 10, No 6.

[136] Sedik, T. S. and T. Sun (2012). Effects of capital flow liberalization-What is the evidence from recent experiences of emerging market economies? IMF Working Paper, Vol. 12 (275).

[137] Solow R. M., (1956). A contribution to the theory of economic growth, Quarterly Journal of Economics, 70, 65-94.

[138] Stensnes, K. (2006). Trade openness and economic growth: Do institutions matter? Norsk Utenrikspolitisk Institutt, No.702-2006.

[139] Stokey, N. L., (1988). Learning by doing and the introduction of new goods, The Journal of Political Economy, Vol. 96. (4): 701-717.

[140] Tiwari, A. K., and M. Mutascu (2011). Economic growth and FDI in Asia: A panel data approach, Economic Analysis and Policy, 41 (2), 173-188.

[141] Udeaja, E. A. and K. O. Obi (2015). Determinants of economic growth in Nigeria: evidence from error correction model approach, Developing Country Studies, Vol. 5, No.9.

[142] Udeaja, E. A. and K. O. Obi (2015). Determinants of economic growth in Nigeria: Evidence from error correction model approach, Developing Country Studies, Vol.5, No.9.

[143] Ugochukwu, U. S., O. A. Okore, and J. O. Onoh (2013). The impact of foreign direct investment on the Nigerian economy, European Journal of Business and Management, 5 (2), 25-33.

[144] UNCTAD (1999). Comprehensive study of the interrelationship between foreign direct investment (FDI) and foreign portfolio investment (FPI), World Investment Report, United Nations, New York.

[145] UNCTAD (2006). World Investment Report, United Nations, New York.

[146] World Bank (2006). World Development Indicators, Washington D. C.

\footnotetext{
*Corresponding author.

E-mail address: taiwogabrielbalogun@gmail.com/okaforjohn2013@gmail.com/osebaryl@ yahoo.com
} 